\title{
The controversies between Jacobo Fratín and Vespasian Gonzaga on the project of the citadel of Pamplona in the late sixteenth century
}

\author{
V. Echarri \& A. Galiano \\ Department of Building Construction, University of Alicante, Spain
}

\begin{abstract}
The design and construction of the citadel of Pamplona required the delineation of numerous drawings by the most prestigious military engineers of the time. After the initial draft, prepared by Jacobo Palear Fratín in 1571, numerous disputes about technical aspects of the design of citadels happened between the different schools and family sagas. The search for the perfect machine of defence and the solution of the conflict between the different design opinions, forced to develop an increasingly accurate maps. Through this graphic documentation, the Council of War could take appropriate decisions in the distance, always under the paradigm of the citadel of Antwerp. The existing intimate relationship between written discourse and the image discourse in each project makes possible to reconstruct the history of the building.
\end{abstract}

Keywords: Fratin, Vespasian Gonzaga, fortifications, citadel of Pamplona.

\section{Introduction}

"Lo mas acertado en estas materias de fortificaciones es que despues de resuelta una vez y empeçada un openion no conviene admitir otra aunque aia conocida mejoría." Tiburcio Spannocchi. AGS. E. 1146-28.

At the time of the birth of modern states, artillery development forced the design of a new concept in fortification: the bastion. This transformation, in turn, resulted in some monarchies, like the Spanish in the sixteenth century, creating a new centralised administrative system in order to carry out supervision on fortifications. The King and his War Council sent military engineers to carry out 
in situ site inspection projects on strongholds [1] in order to better understand the work undertaken by engineers' continual design projects.

The modernisation of fortifications in the kingdoms of Felipe II had, as happened with his predecessor Carlos $\mathrm{V}$, involved military engineers from Italy and Germany [2]. After the death of military engineer Juan Bautista Calvi in 1565, the King gave overall responsibility to his counterpart Jacobo Palear Fratín who, along with Juan Bautista Antonelli, had the full trust of the monarchy. Fratín oversaw work on the peninsular upon his appointment [3]. On many occasions he personally visited and oversaw royal order projects to greatly strengthen fortifications.

There had been bitter disputes between engineers who had already surveyed the same areas and had prepared other fortification blueprint plans. Everyone involved wanted to demonstrate their technical skills and gain the King's favour [4]. It was said in good humour that this competition was "like doctors, one contradicts the other causing further damage and harm to the sick" but also highlighted an all too familiar saga that projects like these were born out of conflicting principles.

\section{Jacobo Palear Fratín's design}

The design of the citadel of Pamplona under Felipe II is of paramount importance to the history of fortifications in Spain. It was the first of only three towns that were made in the Peninsula, therefore worth devoting a detailed study, made possible thanks to the surviving graphic documents located in the General Archives of Simancas (AGS).

The construction project management plan involved several highly-regarded military engineers, foremen and siege warfare specialists. The first was Palearo Giacomo, whose name was hispanicised to Jacobo Palear, but known more amongst his family as Fratino or Fratín in Spanish. He was, until his death in Pamplona in 1586, the lead engineer, comparable only with Antonelli, but thought of as having exceeding talents. Secondly was Vespasiano Gonzaga Colonna, born in 1531 and educated in Sabionetta. He also had a great love of poliorcetics, and collaborated in this regard with Antonelli and Fratín. Vespasiano Gonzaga was accompanied to Pamplona by his private secretary, Antonio de Herrera y Tordesillas, future chronicler of Castille and the Indies.

Following reports by Juan Bautista Antonelli on his first visit to Pamplona, Felipe II commissioned Fratín's project for a pentagonal citadel like that in Antwerp. The engineer drew up the first designs of both the citadel and the city, aided by the data supplied by Calvi and Antonelli in their reports. Shortly after, Vespasiano Gonzaga came to Pamplona in March 1571 as captain and acting viceroy of Navarra, and in the summer Jacobo Fratín This summer moved to the capital of Navarra. Both broadly approved the design of the city, which Antonelli, the viceroy and Juan Manrique were familiar with. Shortly after his arrival Fratín set about a design for the entire city. 


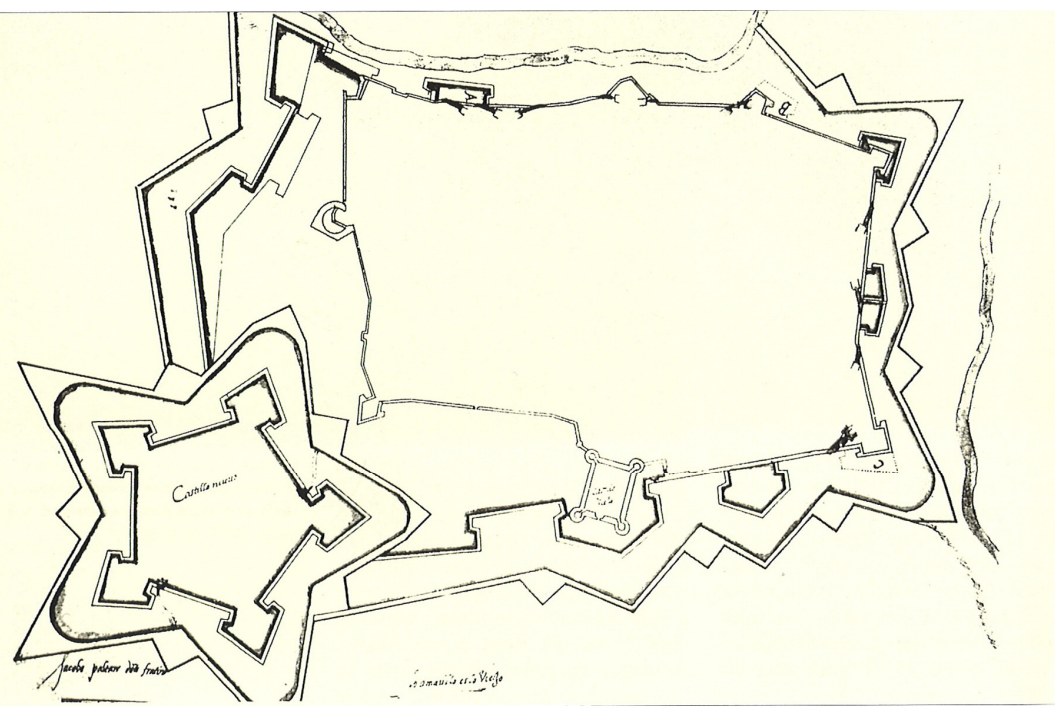

Figure 1: Fratín's general design plans in 1571.

On the citadel, Fratín and the captain-general held a certain difference of opinion. Gonzaga brought 'sketches' and 'outlines' that were preserved freehand drawings. Neither expert could agree on the location of the citadel, the size of the defences, the design of bunkers, trenches and footpaths. "The Duke of Medinaceli, Mr. Juan Manrique and the Engineer Antonelli tried to make it so close to the city that it was necessary to demolish too many houses for providing it with a moat and a square, Vespasiano left this initiative and moved it outwards in order to make the bulwarks bigger and left the water source inside" [5]. Gonzaga's strong opinion was to introduce major changes and it was essential that Fratín drew up an outline of a new plan for the citadel in which changes were to be made, but he did not carry out all that Gonzaga had asked.

On 11th July 1571, Vespasiano Gonzaga and Fratín attend the solemn unveiling of the works performed. The enthusiasm of Gonzaga was apparent in the development of the project and its layout and, Herrera, in a memorial in 1589, reaffirmed "the Pamplona Citadel was like a daughter to him" [6].

Taking advantage of their trip to Pamplona, Gonzaga and Fratín examined the fortifications of Hondarribia and San Sebastian. Both had input later in other places, such as the castle of Alicante, where Gonzaga said ironically of Fratín, after fierce criticism of his draft, "it seems to me that it is impossible for him to be a well-understood man" [7]. The controversy had focused around a misinterpretation of Fratín's proposals by Gonzaga, we are uncertain of any intentional misconduct. Fratín has left an opening which was built in the front for access, but there was nothing in the designs for one. Gonzaga hypothesised that the opening was ineffective and had a highly negative impact on the castle's defences [8]. 


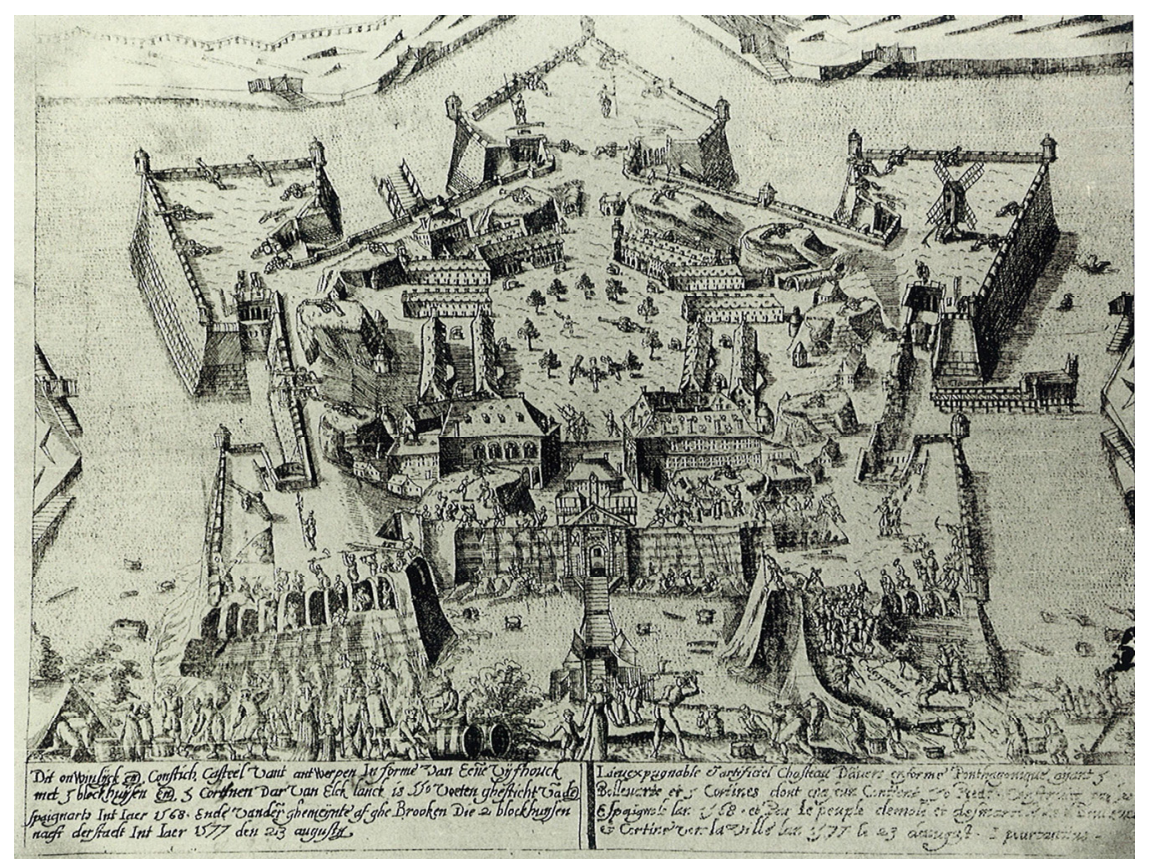

Figure 2: Citadel of Antwerp.

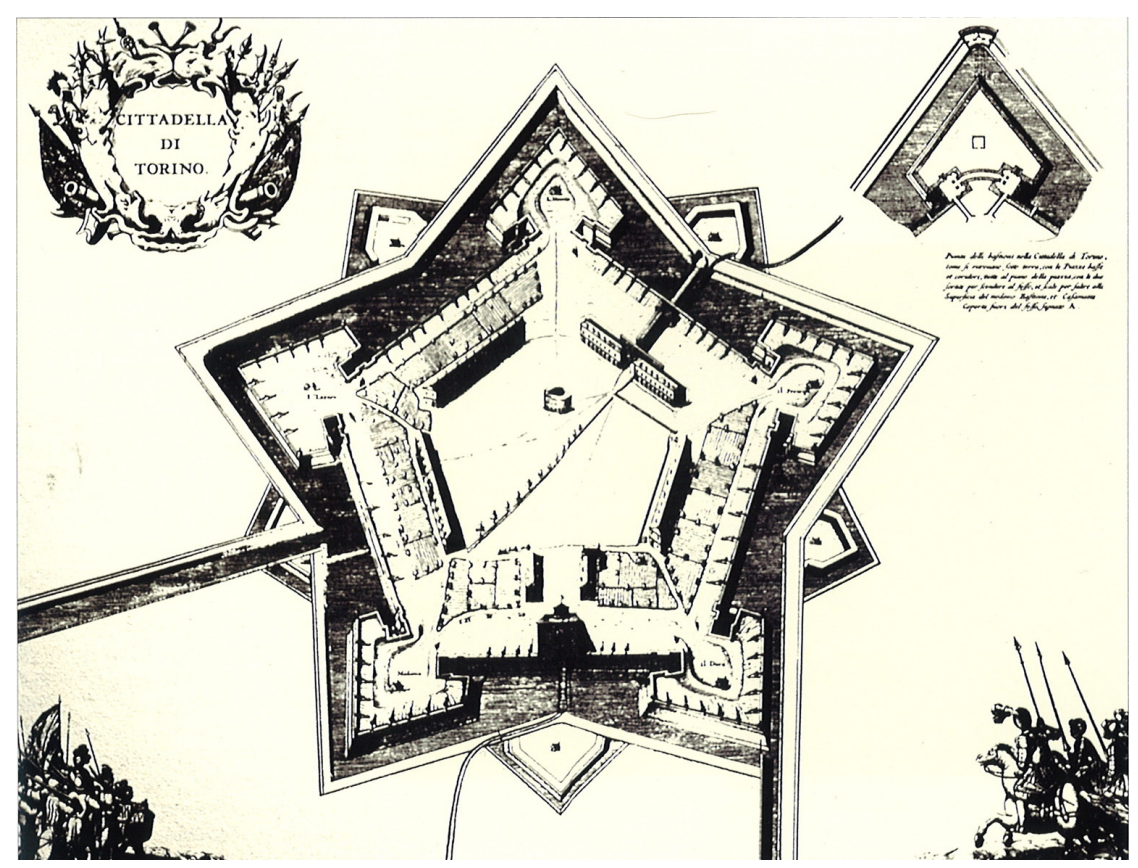

Figure 3: Citadel of Turin.

WIT Transactions on The Built Environment, Vol 143, (C) 2014 WIT Press www.witpress.com, ISSN 1743-3509 (on-line) 
In late 1574 they returned to Pamplona to consider a design Fratín had created for the city, or at least a part of it, demonstrating the need for a little more fortification on the east facade. Shortly after, probably in early 1575, Fratín and the viceroy left Pamplona. Vespasiano Gonzaga was never to return to the city, choosing instead to leave a well-defined project, outlined by Herrera in 1589: "he left behind a very well-planned project". However, later hints that Fratín altered this arrangement: "I'm not quite sure that Jacobo Fratín followed all of Vespasiano plans, I suspect he altered some of them" [9]. The most apparent and pressing problem was well defined bunkers, a fundamental element of the defence. Fratín developed numerous detailed drawings, and followed the advice of Gonzaga, who advised him to follow the guidelines used in Turin and Antwerp [10], which were paradigm pentagonal fortresses of the time.

On 13th November 1584, Jacobo Palear Fratín came to Pamplona for the final time to inform the King about the progress of the works, choosing to spend the entire year of 1585 in Pamplona. He found that the works had been followed in accordance with the orders and designs given by the king. They were well carried out but little progress was made due to lack of funds. He died in the capital of Navarra in late 1585 or early 1586.

\section{The pentagonal design of the citadel}

To reconstruct the project and modifications put forward by Jacobo Fratín we have consulted various originals and copies of blueprint designs. (Many of them should exist, among general plans, detailed plans and models. In general, commands in the building site were verbally transmitted and detailed plans were only developed for communicating information about the more complex parts, as it was done before during the construction of the citadel of Amberes [11].) The most important was published in Idoate [12] (Fig. 1). It's quite a simple, drawn line, with some enhanced shades. There are signs that this was a project drawn up by Fratín: trenches with counterscarps, not parallel to the facades of the bastions. These bastions are small, as Gonzaga had criticized. Also reflects the close proximity of the new fortress to the city. It is without doubt the first draft the engineer made of the citadel, and therefore we date it somewhere around 1571.

The other design of the city and citadel dates back to 1608, and is signed by "Francisco Palear Fratín" Jacobo's nephew (Fig. 9). Compared to the earlier plans it shows that the citadel in a farther position from the city and the ramparts of the citadel are thicker, just like those wanted by Gonzaga. This must be the second project that Fratín carried out he discussed his differences with Gonzaga and the king outlined what guidelines should be followed.

These were the general plans. But plans of two floors of the citadel were retained in the General Archive of Simancas signed with the name "Fratín", which were conserved among 1597 papers. The first includes only two bastions of San Anton and Victoria overlooking the city (Fig. 4). This is a presentation design, drawn with great care. We do not know if it's an original of Jacobo or a copy made by his brother Jorge, who in 1597 was in charge of the works. The interesting thing about this design is that it precisely defines the casemates, with 
high and low breastwork, and the access vaults through the embankment on the inside, which corresponds with the state Jacobo Fratín found it in 1578 and the sizes of the defences are the changes Gonzaga made.

The second plan of the citadel, complete and isolated, is a very detailed and carefully drawn design (Fig. 5) which was more than likely drawn in 1597, or shortly before, and the inscription, more than doubtful, refers to Francisco Palear Fratín, nephew of Jacobo. It is unlikely that this was the author because of the differences found with the proposals done by his uncle and his own ones shown in the plan drawn at 1608 (Fig. 9). The proposal shows Gonzaga's and Spannocchi's guidelines and corrections to Fratín's project.

The highlight of the comparison of the two designs lies in the arrangement of the counterscarps, since the rest of the elements and their proportions are identical. In the foreground, Fratín followed the guidelines to have sharp pits, and proved to hold in the moat better. It is a characteristic of Fratín, as already mentioned, used in other places like Goleta. In contrast, in the second, the counterscarps are parallel to the facades of the bastions. We can say without a doubt that should the amendments set out by Gonzaga or Tiburcio Spannocchi, designer of a similar project for the Cidadel in Jaca in 1592, were applied to these works in 1596. We know therefore that Fratín's second draft of the citadel of Pamplona followed the model in Antwerp, though twenty percent smaller, thanks in part to the provisions of Gonzaga.

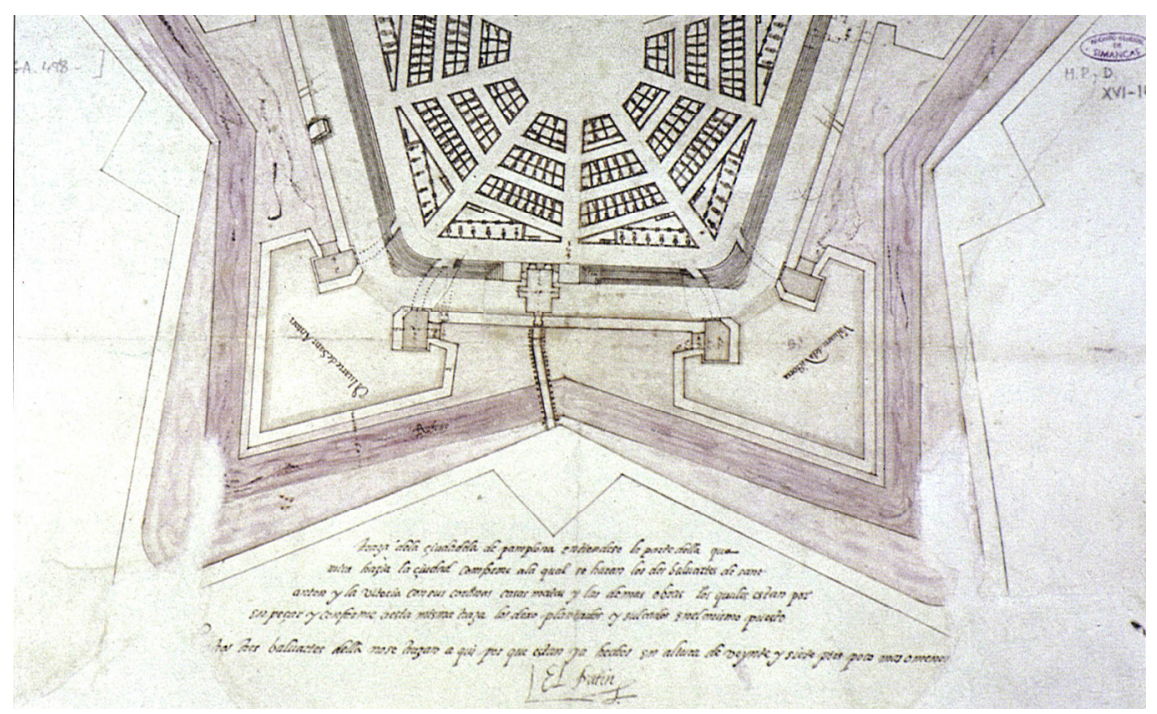

Figure 4: Jacobo Palear Fratín. Design of the citadel overlooking the city, 1586 . 
Defence Sites II 71

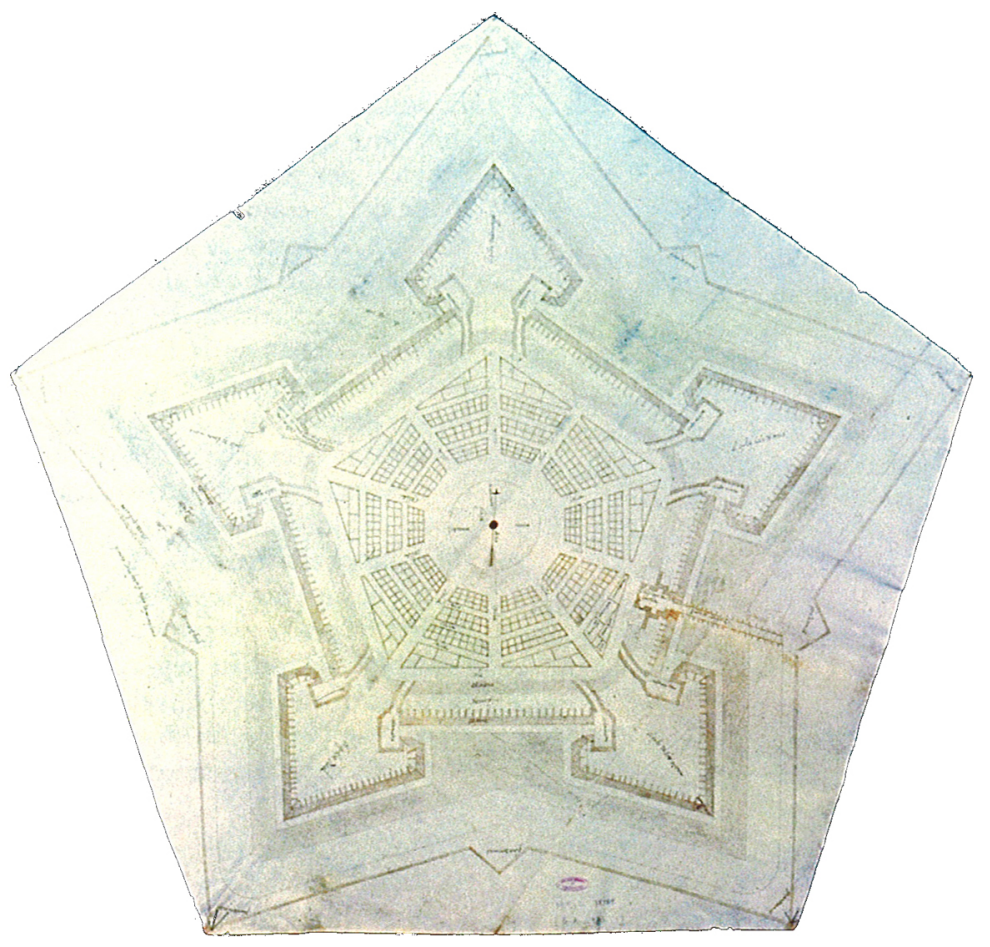

Figure 5: Design of the citadel according to Gonzaga and Spannocchi in 1597.

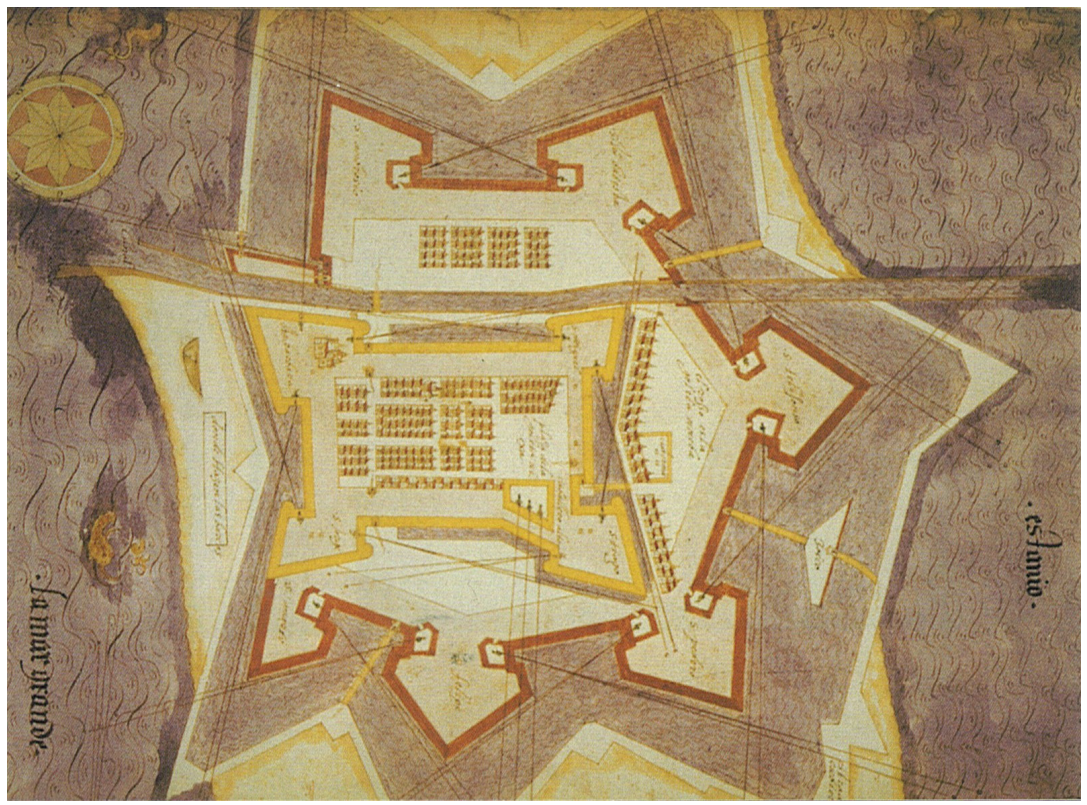

Figure 6: Fratín's design in Goleta. 


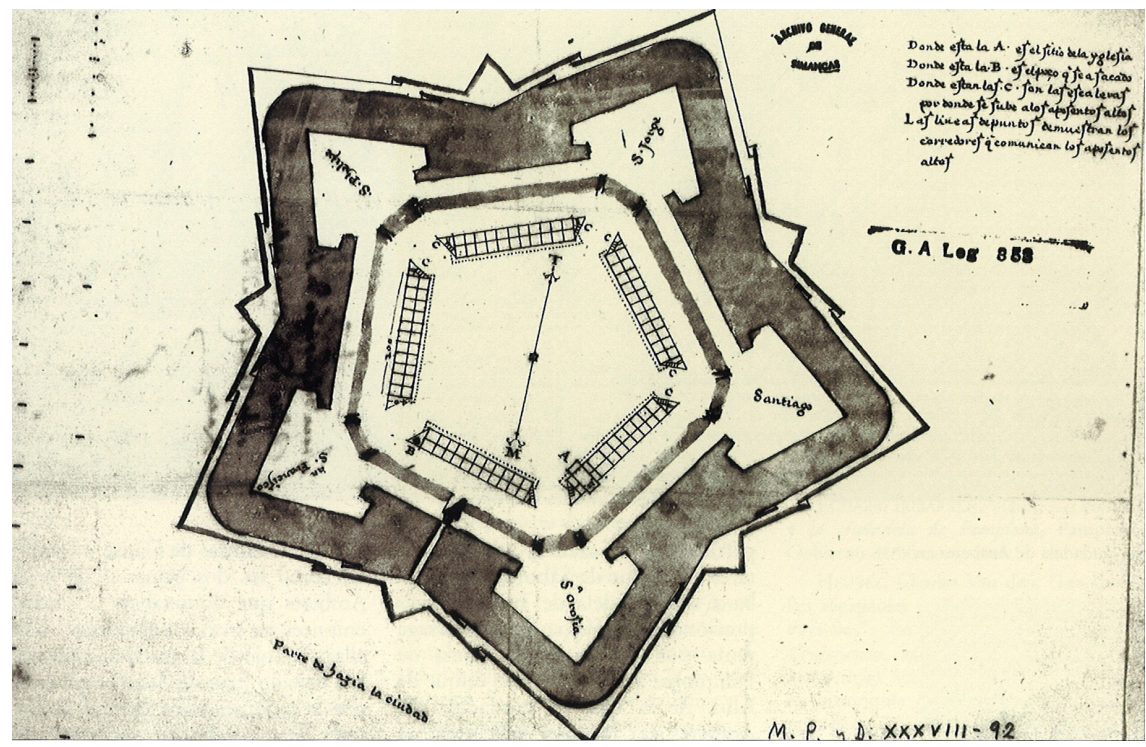

Figure 7: Designs for the citadel of Jaca. T. Spannocchi, 1592.

\section{Jorge Palear Fratín and his enemies: Tiburcio Spannocchi's opinion}

On his death, Jacobo Palear Fratín was replaced by his brother Jorge to carry out the designs. These were times of tension and bitterness with other people and conflict between different groups, which was fuelled by personal enmity.

Opposition to Jorge Fratín focused firstly on not following the designs of his brother Jacobo, which was without doubt apparent. Already in Mallorca, Jorge Fratín had tried altering the designs of his brother [13], which we know in sufficient detail due to the fact that stones from the Castle of Santiago were taken for construction of the citadel. The difference in size made them seem like poor patchwork. There is an interesting image proving this small fact (Fig. 8). Faced with this difficult situation the War Council convened on 6th October 1587 that the designs produced by Jacobo Fratín will continue "without change" [14].

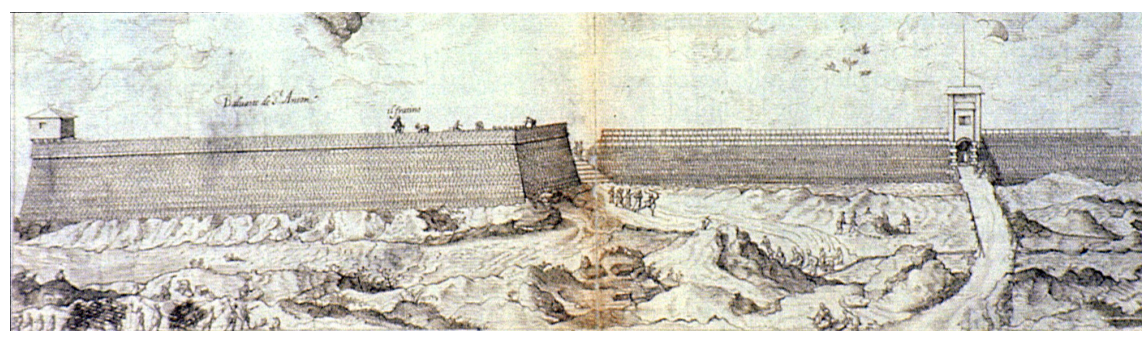

Figure 8: $\quad$ Stronghold of San Antón, 1587. 
Shortly thereafter, probably in late 1588, Spannocchi Tiburcio [15], one of the great experts of the Felipe II fortifications returned to Pamplona. Spannocchi drew up a model there, which unfortunately is not preserved [16].

Spannocchi's opinion was rather negative and echoes of protests were mirrored. It seemed that the walls of the citadel were too low, which could be threatened from the city. "Tiburcio considered that the city wall was too low and also the casemates. The height of the fortification walls should be normally as to be out of scale" [17]. He advised raising the height of the bastions and covers. The bunkers were also too low, and seemed easily accessible. Spannocchi, also rejected the small trenches, which had no understood role, and found them easily usable in case of a siege. The document also added the idea that making a wet tiny moat inside the big moat was not a bad decision, "because when the enemy reaches a big moat, and considering that they only have to cross it, finding another one, deep and full of water, placed against the forces" [18].

After Spannocchi visited Pamplona and his accusations against Fratín and Gonzaga, the War Council began to investigate what happened. Antonio de Herrera came to the defence of the viceroy and he prepared a comprehensive report in 1589, which also included testimony from that of Gonzaga himself. He defended the viceroy: "I'm not quite sure that Jacobo Fratín had followed Vespasiano's orders" [19]. The issue of small trenches was dealt with in more detail; these were not Gonzaga's designs, as he had always wanted a deep, clean pit. All the defects in execution came from Jorge Fratín, who changed his brother's draft.

The Council decided once again that the draft Jacobo Fratín be followed. Felipe II visited Pamplona in 1592, and took an inspection of his citadel, although the works were at a very slow pace. L'Hermite accepted the king's consideration: "According to your plan, it could be seen that it would be one of the best of Christianity, not finding many differences with Amberes" [20].

Shortly after Jorge Fratín's son, Francisco, began to figure in Pamplona. Many of the original papers Jacobo Fratín had passed to Jerónimo Marqui, were burned in his home in El Escorial [21]. This was a small disaster that has prevented us from further knowledge regarding the casemates and moats.

Francisco Fratín probably did not have great skills and was not on good terms with Marqui. Soon after he was modifying the design left by Jacobo Fratín. A design made in 1608, to which we have previously referred, gives us enough evidence to guess it consisted of change (Fig. 9). Marchi states that there were remaining uncorrected defects that date to 1604: "these works are the same mistakes that were made in '96" [22]. This shows the trench design was to be maintained from Fratín's first plan.

The defect Francisco introduced consisted of two bastions located at the connection of the city with the citadel. They were against that of a good defence, according to some experts and it was thought necessary to bring back Spannocchi, Senior Engineer of the Kingdoms of Spain, to Pamplona. The defences of Francisco were dropped, at that time, and the moat was widened and cleaned, with counterscarps parallel to the facades of the bastion. 
74 Defence Sites II

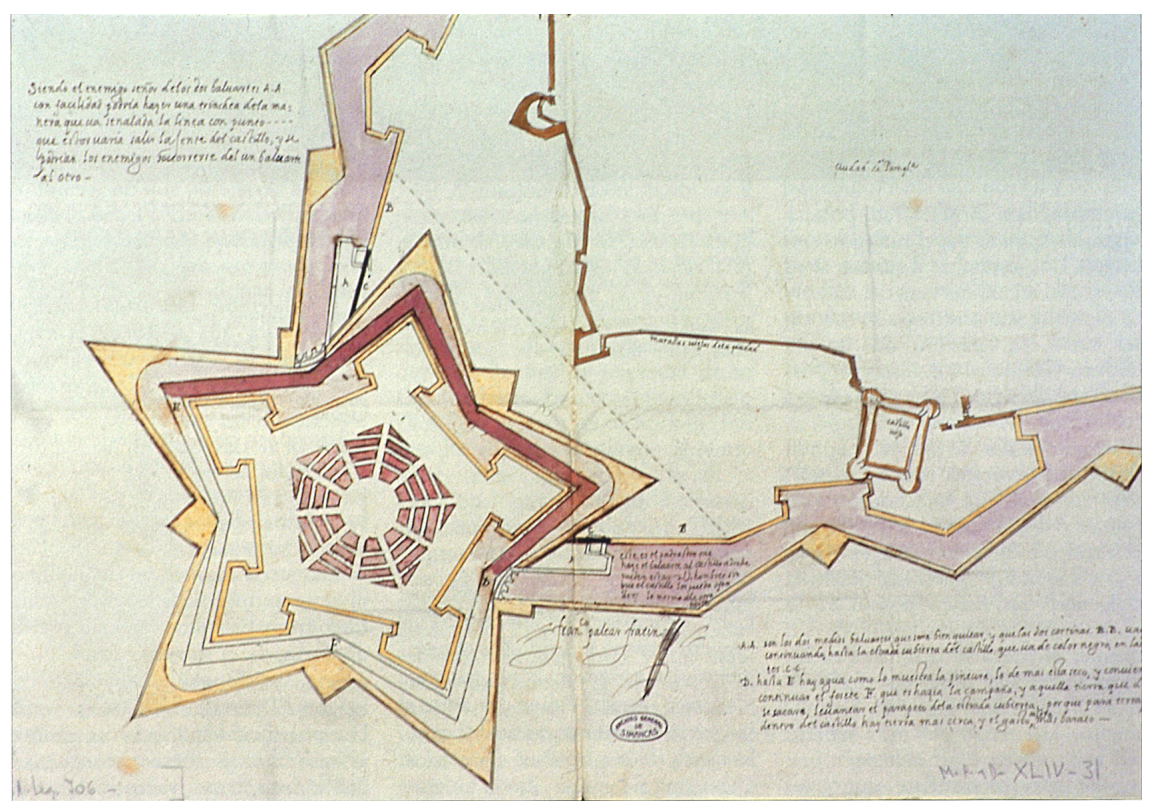

Figure 9: Francisco Fratín's project in 1608.

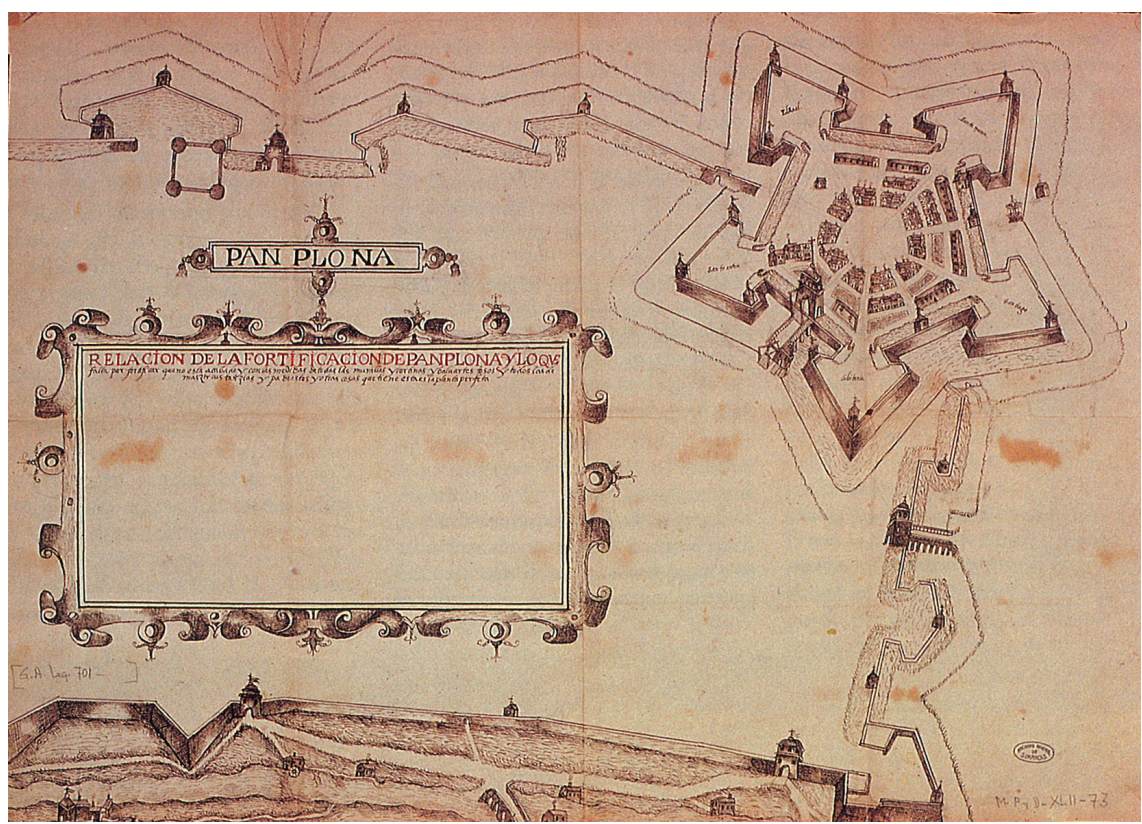

Figure 10: The Citadel, 1608. (Francisco Palear Fratín.) 
The construction of the citadel of Pamplona required successive projects to reach the desired perfect defence. Throughout the seventeenth and eighteenth centuries important proposals affecting its original design, particularly in regard to its bastions, counterguards and ravelins followed [23]. The progressive artillery development forced new technical advances that engineers the likes of Alexander Rez, Ignacio Sala, Prospero Jorge de Verboom or Juan Martin Zermeño applied. Fratín's original design can be recognised through graphical documentation retained and attentive study.

\section{Conclusions}

The citadel of Pamplona, which is preserved in the General Archives of Simancas (AGS) as graphic documentation, allows us to understand the evolution of the project in its early decades and disagreement among the most experienced engineers of the time. Through this documentation discrepancies between Fratín and Gonzaga could be tracked, which could not be clarified by other means. The fact that the Fratín's citadel was located too close to the city was due to the possibility of the existence of a natural source, causing wet trenches. For Gonzaga this was an error that prevented making a good defence in front of the two bastions, and allowing the enemy on the inside to be protected by buildings and could fire artillery.

The fact that the trenches were divergent could only be observed through visual documentation, as written documents do not appear in any of the reports preserved in the AGS. It was undoubtedly an important element of controversy, being one of the most interesting debates of the time on fortification. This was a similar dispute which subsequently occurred in Denia and Alicante between the two experts, in which a misinterpretation by Gonzaga on Fratín's designs led him to give harsh criticism; criticism that could have been avoided if the engineer had left a well-defined "blueprint" of his project.

\section{References}

[1] Quatrefages, R., La fortificación en España durante el Renacimiento. Temas de Historia Militar: ponencias del Primer Congreso de Historia Militar, (1983), pp. 133-142. Madrid: Servicio de Publicaciones del E.M.E.

[2] Cámara Muñoz, A., Fortificación y ciudad en los reinos de Felipe II. Madrid: Nerea S.A, 1998.

[3] Viganò, M., "El fratin mi ynginiero". I Paleari Fratino da Morcote ingegneri militari ticinesi in Spagna (XVI-XVII secolo). Bellinzona: Edizioni Casagrande, 2004.

[4] Capel, H., Sánchez, J. E., Moncada, O., De Palas a Minerva. La formación científica y la estructura institucional de los ingenieros militares en el siglo XVIII. Madrid: Serbal, Barcelona y CSIC, 1988.

[5] Institute of Military History and Culture, Madrid (IHCM). Colec. Aparici, t. I, fol. 198. 
[6] IHCM. Colec. Aparici, t I, fol. 202.

[7] AGS. GA. Leg.79, n. 102.

[8] Echarri Iribarren, V.; Pérez Millán, M. I.; González Avilés, A. B., La competitividad de Vespasiano Gonzaga y el Fratín sobre la modernización de las estructuras del castillo de Alicante en la segunda mitad del siglo $X V I$. Paper presented to the 14th International Congress of Architectonic Graphic Expression. Oporto, 2012. Servicio de Publicaciones de la Universidad de Valladolid. Valladolid, (2012), pp. 105-110.

[9] IHCM. Colec. Aparici, t. I, fol. 202v.

[10] Fara, A., Il sistema e la città. Architettura fortificata dell'Europa moderna dai trattati alle realizzazioni (1464-1797). Milán: SAGEP, 1989.

[11] Van Der Heuvel, Ch., El problema de la ciudadela: Amberes. La función de los diseños y memorias en la segunda mitad del siglo XVI, in: Seta, C. De; Le Goff, J. (eds.). La ciudad y las murallas. Ed. Cátedra. Madrid (1991), pp. 181.

[12] Idoate, F., Las Fortificaciones de Pamplona a partir de la conquista de Navarra, en Príncipe de Viana, no 54-55 (1954), pp. 57-154.

[13] Estabens Ruiz, F., De lo bélico mallorquín. Fuerzas militares de Mallorca. Arquitectura militar insular, in: Mascaro Pasarius, J. Historia de Mallorca, T. IV. Ed. J. Mascaró Pasarius. Palma de Mallorca (1971), p. 584.

[14] IHCM. Colec. Aparici, t. I, fol. 186.

[15] Cámara Muñoz, A., Tiburzio Spannocchi, Ingeniero Mayor de los reinos de España. Espacio, Tiempo y Forma, n 2 (1988), pp. 77-90.

[16] IHCM. Colec. Aparici, t. I, fol. 202v.

[17] IHCM. Colec. Aparici, t. I, fols. 204v-205.

[18] IHCM. Colec. Aparici, t. I, fol. 203.

[19] IHCM. Colec. Aparici, t. I, fol. 202.

[20] L'Hermite, J. Le Passetemps. E. Ouverbaux y J. Petit. Amberes, 1896.

[21] Letter from Captain General of Navarra, Mr. Martín de Córdoba, June, 7th, 1589. SHM. Colec. Aparici, t. I, fol. 190.

[22] SHM. Colec. Aparici, t. I, fols. 512-512v.

[23] Cfr. Echarri Iribarren, V. Las Murallas y la Ciudadela de Pamplona. Pamplona, Departamento de Educación y Cultura-Institución Príncipe de Viana, Gobierno de Navarra, 2000. 